\title{
Metawartości i spór wokół ochrony środowiska naturalnego
}

\section{Meta-values and the Conflict over Environmental Protection}

\begin{abstract}
In the political sphere, two antinomous attitudes towards the nature are permanently present. The first one is characteristic of the left-wing and the second one of the right-wing. The article explains the content and source of these attitudes by referring to Shalom H. Schwartz's psychological value theory (SVT) and the circular meta-value model created on the basis of its adaptation.
\end{abstract}

Keywords: environmental protection, left, right, center, meta-values

\section{Kołowa i linearna struktura wartości politycznych}

W artykule zostanie wykazane, że metawartości północne i południowe modelu kołowego determinują wykluczające się postawy wobec środowiska naturalnego. W pierwszej kolejności zostaną przedstawione założenia tego modelu, a w drugiej - wskazane przykłady związku między poparciem dla metawartości północnych i postawą prośrodowiskową z jednej strony a poparciem dla metawartości południowych i postawą traktującą środowisko w sposób utylitarny - z drugiej strony.

Wartości, które są obecne w sferze publicznej (w programach wyborczych, debatach, deklaracjach politycznych, w decyzjach politycznych), będą w dalszej części artykułu określane mianem metawartości ${ }^{1}$. Tego typu aksjomaty można scharakteryzować w następujący sposób: 
1. Metawartości są abstrakcyjne, co oznacza, że nie można ich zredukować do innego typu wartości. Przykładem takich aksjomatów są: wolność, równość, władza, progresywizm, religia lub tradycja.

2. Konflikty aksjologiczne $\mathrm{w}$ demokracji wynikają $\mathrm{z}$ antynomii metawartości, które w okresie rewolucji francuskiej otrzymały etykiety lewicowych i prawicowych. Źródła tej sprzeczności tkwią w opisanym przez psychologa Shaloma H. Schwartza konfliktowym układzie wartości podstawowych (Schwartz, 1992, s. 1-65).

3. Metawartości to cele motywacyjne, którymi kieruje się wspólnota (społeczeństwo). W demokracji wskazujemy na te cele, oddając swój głos na podmioty deklarujące poparcie dla określonych typów wartości. Demokracja jest jedynym systemem, który daje wyborcom możliwość wskazania aksjomatów, które będą brane pod uwagę w procesie decyzyjnym.

4. Postulaty programowe są tworzone na podstawie metawartości. Na przykład idea podatku progresywnego została skonstruowana na podstawie lewicowej metawartości równość. Z kolei koncepcja budżetu partycypacyjnego jest pochodną metawartości samowładność. Propozycje zaostrzania polityki migracyjnej są ukierunkowane na obronę prawicowych metawartości wspólnota i tradycja. Postulaty polityczne są pochodnymi jednej lub kilku metawartości.

5. Metawartości są społecznym odbiciem antynomii modelu Schwartza ${ }^{2}$ i można je ułożyć w obrębie wyróżnionych przez tego autora czterech typów głównych („umacnianie siebie” - „przekraczanie siebie” oraz „zachowawczość” - „otwartość na zmiany”) w sposób odpowiadający opisanym przez niego regułom zgodności i konfliktu.

6. Metawartości są istotne dla jednostki, ponieważ mogą wspierać lub blokować realizację wartości podstawowych. Jeśli władzę polityczną przejmuje partia chrześcijańsko-demokratyczna i na poziomie centralnym wysoki priorytet uzyskuje metawartość religia (której jednym z założeń jest obecność wiary w sferze publicznej), sytuacja taka nie będzie akceptowana przez osobę, która nadaje wysoki priorytet wartościom podstawowym w ramach typu „otwartość na zmiany” (realizacja religii narusza jej osobistą hierarchię wartości).

W stosunku do zaproponowanego poniżej modelu trzeba uczynić dwie uwagi. Po pierwsze, macierz metawartości można wykorzystać w analizie obejmującej systemy polityczne spełniające proceduralne kryteria demokracji. W totalitaryzmie i autorytaryzmie obywatele nie mają możliwości wskazania preferowanych przez siebie aksjomatów. Tym samym analizowanie fragmentów

Korelacje między wartościami podstawowymi na poziomie indywidualnym oraz państwowym (individual and country level) wykazały badania psychologiczne: Fischer, Vauclair, Fontaine et al., 2010, s. 135-151. 
ideologii w systemach niedemokratycznych jako "lewicowych”, „centrowych” lub „prawicowych” jest zabiegiem ryzykownym logicznie. Po drugie, wartości różnią się w poszczególnych kręgach cywilizacyjnych (Routamaa, Brandt, 2008). Kołowy model metawartości jest propozycją ukierunkowaną na państwa cywilizacji zachodniej w granicach określonych przez Samuela P. Huntingtona (Huntington, 1996).

Zgodnie ze schematem 1 północna strona macierzy jest zarezerwowana dla aksjomatów lewicowych. Lewicowość jest wyznaczana przez siedem metawartości: równość, społeczeństwo, wolność jednostki, samowładność, pluralizm systemów wartości, progresywizm i racjonalizm. Wyróżnione nazwy mają charakter umowny, natomiast kluczowy jest ich sens, wyznaczający polityczne cele motywacyjne na poziomie państwa i społeczeństwa.

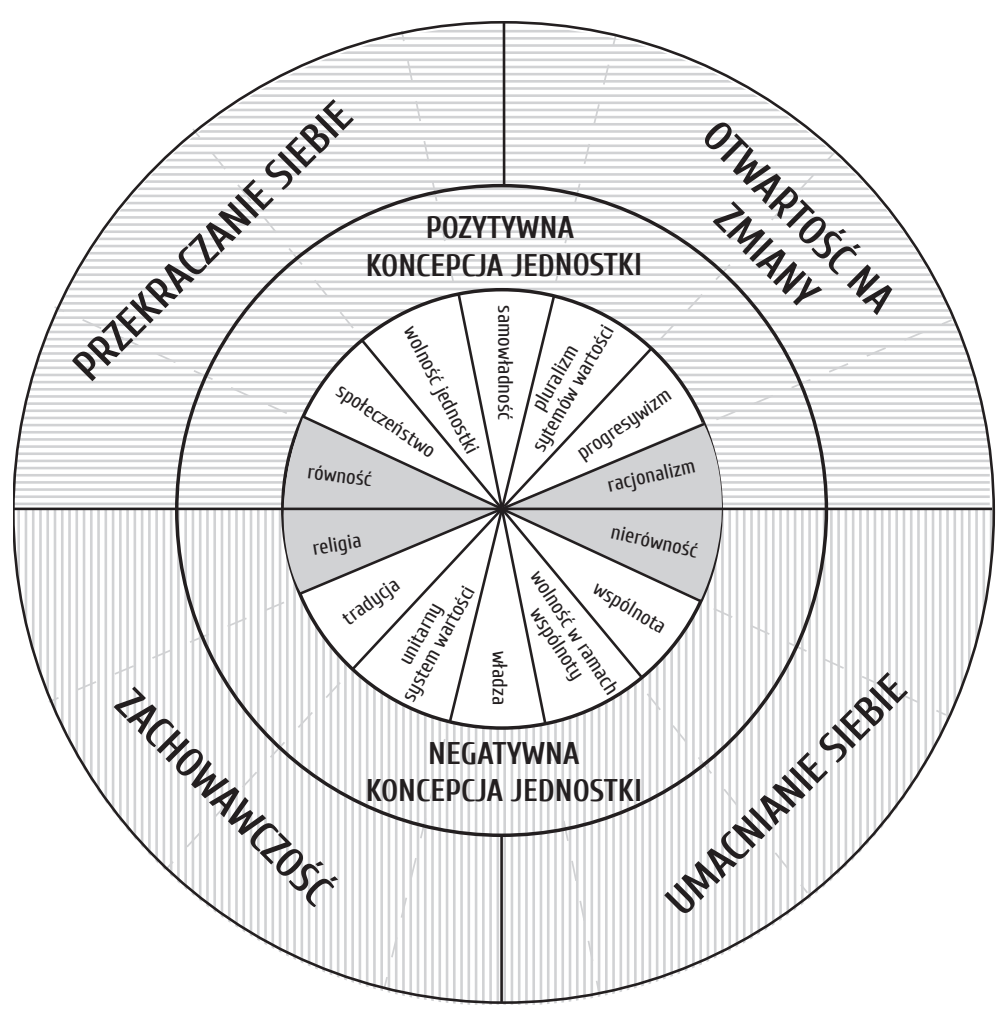

Schemat 1. Kołowa struktura metawartości (Maj, 2018, s. 148)

Równość jest aksjomatem obecnym w wymiarze ekonomicznym, politycznym i społecznym, na jej podstawie tworzone są programy socjalne i postulaty ograniczania przywilejów. Równość jest uzasadniana sprawiedliwością, która ma odniesienie społeczne i dystrybutywne, jest zakotwiczona w ramach typu 
„przekraczanie siebie” i zorientowana na innych (słabszych, dyskryminowanych).

Cechą społeczeństwa jest uniwersalizm i wyjście poza granice państwa. Jest to wizja jednostek przejawiających aktywność społeczną i polityczną. Przynależność do społeczeństwa ma charakter subiektywny (czynnikiem przesądzającym jest odczucie przynależności ze strony zainteresowanej osoby). Jednostka staje się równoprawnym członkiem społeczeństwa po spełnieniu wymogów formalnych (np. związanych z uzyskiwaniem obywatelstwa). Jest to niezależne od przekonań, języka, wiary czy innych atrybutów. Obywatele powinni przejawiać aktywność społeczną, działać na rzecz innych. Powinni angażować się w politykę, ponieważ wysoka frekwencja wyborcza jest miarą jakości demokracji.

Wolność jednostki jest definiowana możliwie szeroko; obywatele posiadają rozbudowany katalog uprawnień, w tym osobistych, decyzyjnych. Granice wolności jednostki są wyznaczone zasadą imperatywu kategorycznego Kanta. Wspomniana reguła została sformułowana w rezultacie filozoficznych poszukiwań, zmierzających do ustalenia uniwersalnych zasad etycznych określających postępowanie jednostki bez odwoływania się do religii. Upraszczając, jej treść jest następująca: należy postępować wedle takich norm, co do których chcielibyśmy, aby były stosowane wobec każdego i zawsze (Singer, 1954).

Samowładność jest ukierunkowana na demokratyzację struktur hierarchicznych. Państwo istnieje dla obywateli i jest emanacją ich woli. Sytuacją pożądaną jest podejmowanie decyzji bezpośrednio przez rządzonych lub na możliwie niskich szczeblach przedstawicielskich. Decentralizacja prowadzi do zwiększenia podmiotowości członków społeczeństwa. Formułowanie polityki na niskich szczeblach decyzyjnych wymusza uwzględnianie różnych argumentów, punktów widzenia i prowadzi do rozwiązań konsensualnych³.

Pluralizm systemów wartości jest dążeniem do świata wolnego od odgórnych nakazów i autorytetów moralnych. W praktyce oznacza to sprzeciw wobec politycznych prób ustalania „jedynego" systemu wartości. Wysuwany jest argument, że zdefiniowanie moralności w ramach jednego systemu wartości nie jest możliwe, ponieważ interpretacje podstawowych aksjomatów są subiektywne (na przykład w ramach etyki istnieje kilkadziesiąt definicji dobra). Celem pluralizmu systemów wartości jest więc stan, w którym w sferze publicznej swobodnie funkcjonuje wiele różnych systemów wartości, z kolei instytucje państwa, uznając je za równoprawne, nie faworyzują ani nie dyskryminują żadnego z nich.

Podstawą metawartości progresywizm jest wiara w nieuchronny rozwój, postęp cywilizacyjny, technologiczny i gospodarczy. Celem progresywizmu jest „wyzwolenie człowieka od krępującego gorsetu tradycji, obyczajów, narzuconych zobowiązań i w rezultacie poszerzenie obszaru wolności jednostki” (Reykowski,

Lewicowa samowładność jest metawartością opartą na ujęciu horyzontalnym, w przeciwieństwie do prawicowej władzy, w której stanem naturalnym jest istnienie hierarchii. 
2011, s. 47). Rezygnacja $\mathrm{z}$ tradycji nie jest dążeniem samym w sobie, ponieważ odrzucana jest przede wszystkim ta jej część, która blokuje zmiany społeczne i możliwość samodoskonalenia człowieka.

Racjonalizm jest dążeniem do sekularyzacji nie tylko instytucji państwa, ale generalnie przestrzeni publicznej. Jest oparty na założeniu, że nie istnieją wydarzenia ani procesy nadprzyrodzone, rzeczywistość można wyjaśniać wyłącznie w odniesieniu do wiedzy naukowej; religia jest sprawą prywatną obywateli i jako taka nie powinna w żaden sposób oddziaływać na sferę publiczną. Racjonalizm jest oparty na takich schematach relacji pomiędzy państwem i Kościołem, które wprowadzają rozdział instytucjonalny, a patrząc z perspektywy władzy państwowej - zapewniają suwerenność aksjologiczną.

Południowa strona modelu obejmuje typy: „umacnianie siebie” oraz „zachowawczość" i w polityce jest zagospodarowana przez prawicową nierówność, wspólnotę, wolność $w$ ramach wspólnoty, władzę, unitarny system wartości, tradycję oraz religię.

Nierówność polega na uznaniu różnic istniejących między ludźmi za naturalne, wynikające z cech jednostek, posiadanych przez nie zdolności i pozycji społecznej. Przyjmuje się, że ludzie są niepowtarzalni, a występujące odmienności są warunkiem koniecznym dla rozwoju indywidualnego i społecznego. Konsekwencją tego jest hierarchizacja społeczeństwa, uznawana za naturalną i pożądaną. Nierówność jest (podobnie jak w przypadku równości) uzasadniana sprawiedliwością, lecz sposób jej rozumienia jest zupełnie inny niż w ujęciu lewicowym. Prawicowa sprawiedliwość ma pochodzenie naturalne (Scruton, 2002, s. 102) i jest interpretowana $w$ ramach grupy wartości „umacnianie siebie”. Instytucje państwa nie powinny ingerować w różnice między jednostkami, co dotyczy nie tylko statusu ekonomicznego, ale również społecznego. Lewicowa równość jest postrzegana jako narzucanie wizji społeczeństwa jako monolitu.

Wspólnota jest rozumiana jako historycznie ukształtowana, kulturowa grupa etniczna (naród). Organicyzm i antyegalitaryzm są kluczami w jej interpretacji. Podstawą organicyzmu jest uznanie, że jednostki nie są samowystarczalne i niezależne od wspólnoty, w związku z tym samorealizacja jest możliwa jedynie poprzez uczestnictwo w większej całości. Antyegalitaryzm jest zgodny z prawicową ideą porządku społecznego, mającego swoje źródło w tradycji lub religii. Cele wspólnoty znajdują się w całkowitej opozycji do liberalnej koncepcji autonomii jednostki w ramach społeczeństwa.

Wolność $w$ ramach wspólnoty nie ma charakteru absolutnego, jest ograniczona uczestnictwem jednostki w grupie. To wspólnota wyznacza zakres swobody, tworząc normy moralne i obyczajowe regulujące zachowania jej członków. Punktem wyjścia jest negatywna koncepcja natury ludzkiej, na podstawie której na jednostkę z góry nakładane są pewne ograniczenia. Można je zmniejszać, jeśli istnieje pewność, że nie doprowadzi to do zaburzenia porządku społecznego (Wendelken, 1996). 
Metawartość władza jest oparta na scentralizowanej wizji relacji międzyludzkich. Władza nie jest (jak w światopoglądzie lewicy) środkiem do realizacji zasady równości i sprawiedliwości społecznej, ale „służy do tego, aby rozkazywać i wywierać wpływ" (Scruton, 2002, s. 37). Państwo powinno być silne i posiadać autorytet. Procesy decentralizacji i delegowania kompetencji są oceniane negatywnie, ponieważ prowadzą do ograniczenia autorytetu, zacierania odpowiedzialności za podejmowane decyzje i zmniejszenia efektywności państwa. Z metawartości władza wynika idea depolityzacji społeczeństwa - polityką nie powinni się zajmować wszyscy uprawnieni do głosowania, lecz rządzący. W założeniu ma to prowadzić do ograniczenia konfliktów społecznych, których źródłem jest odmienność filozofii, systemów moralnych i ideologii.

Prawica dąży do unitarnego systemu wartości. Przyjmuje się, że dla wspólnoty (narodu) korzystne jest istnienie wspólnego aksjologicznego mianownika. Dlatego w sferze publicznej wysoko oceniane są aksjomaty skonstruowane w drodze doświadczeń historycznych, zaliczane do hierarchii wartości danej wspólnoty. Wyraźnie wskazywany jest jeden określony system aksjologiczny, a konkurencyjne traktowane są jako potencjalne zagrożenie dla ciągłości wspólnoty. Wartości są przekazywane pokoleniowo przez tradycję, drogą doświadczenia i przy współudziale autorytetów.

Religia jest elementem porządku naturalnego, źródłem hierarchii wartości, także w sferze publicznej. Przyjmuje się, że lewicowa idea neutralności światopoglądowej państwa ma charakter czysto teoretyczny i nie występuje w rzeczywistości, ponieważ sprawujący władzę państwową reprezentują zawsze określony system wartości. System ten w wymiarze moralnym powinien być zakotwiczony w religii danej wspólnoty. Prawica stara się zachować obecność religii zarówno w sferze prywatnej, jak i publicznej. Przejawia się to w: postulacie wzmocnienia instytucji Kościoła, co dotyczy wyboru modelu wsparcia finansowego religii przez państwo, deklarowaniu przywiązania do systemu wartości inspirowanego religią wspólnoty, oparciu norm moralnych, kryteriów oceny słuszności, prawdy i fałszu na religii.

Tradycja jest rozumiana jako przywiązanie do naturalnego porządku, dziedzictwa oraz dbałość o pamięć historyczną wspólnoty. Występuje w dwóch formach (Reedy, 1981). Pierwsza, inspirowana poglądami Edmunda Burke’a, jest oparta na filozofii zmiany jak najbardziej podobnej do stanu poprzedniego i prowadzi do konserwowania rzeczywistości. Druga, utożsamiana z postacią Louisa de Bonalda (lub Josepha de Maistre’a), zmierza do przywrócenia ładu uznawanego za naturalny i odwieczny, co niekiedy wymaga zmiany stanu obecnego (przeprowadzenia restytucji, restauracji). Wspólnym mianownikiem tych dwóch form tradycji jest ciągłość, rozumiana jako utrzymywanie zasad, które przesądzają o ludzkich zachowaniach i tożsamości wspólnoty.

Obowiązująca w macierzy reguła konfliktu prowadzi do wyróżnienia siedmiu par wartości i przeciwwartości. Są to dychotomie: równość - nierówność, 
społeczeństwo - wspólnota, wolność jednostki - wolność w ramach wspólnoty, samowładność - władza, pluralizm systemów wartości - unitarny system wartości, racjonalizm - religia oraz progresywizm - tradycja.

Z kolei reguła zgodności powoduje, że wartości sąsiadujące są do siebie zbliżone. Na przykład prawicowa wartość tradycja jest bliska wartościom unitarny system wartości i religia. Z kolei władza jest bardziej podobna do wspólnoty niż leżąca w północnej części równość. Macierz posiada charakter kontinuum kołowego - im bardziej oddalone są od siebie wartości, tym większe są między nimi różnice.

Na granicy północnej i południowej części modelu znajdują się metawartości styczne. Są to aksjomaty należące do różnych typów wartości, ale jednocześnie do siebie podobne. We wschodniej części wartościami tego typu są racjonalizm i nierówność, a w zachodniej religia i równość. W polityce aksjomaty obszarów stycznych są zapożyczane zarówno przez podmioty samoidentyfikujące się z lewicą, jak i prawicą. Stanowią bufor aksjologiczny, rozdzielający dwa typy światopoglądów - lewicowy, skonstruowany wokół typów „przekraczanie siebie” oraz „otwartość na zmiany”, oraz prawicowy, ukształtowany w ramach typów „umacnianie siebie” i „zachowawczość”.

We wschodniej części modelu wartościami stycznymi są racjonalizm i nierówność. Patrząc z perspektywy północnej, jest to miejsce styczności metawartości lewicowych z prawicową nierównością. Na tym zbiorze wartości zbudowany został liberalizm (społeczeństwo, wolność jednostki, pluralizm systemów wartości, samowładność, progresywizm, racjonalizm, nierówność).

W zachodniej części macierzy na styku dwóch typów wartości znajduje się przestrzeń, w której metawartości prawicowe spotykają się lewicową równością. Patrząc z perspektywy południowej, są to aksjomaty, do których odwołuje się chrześcijańska demokracja (wspólnota, wolność $w$ ramach wspólnoty, władza, unitarny system wartości, tradycja, religia, równość). Zależności dotyczące wartości stycznych są symetryczne - można wskazać na północne inspiracje metawartością religia, które pojawiały się w teologii wyzwolenia, a także na południowe odniesienia do racjonalizmu, charakterystyczne dla nurtu określanego prawicą laicką.

Elementem modelu są funkcjonujące w polityce antynomiczne ujęcia ludzkiej natury (koncepcje jednostki). Patrząc z perspektywy macierzy, ich celem jest uzasadnienie preferencji w kierunku metawartości północnych (lewicowych) lub południowych (prawicowych). Zauważmy, że koncepcja jednostki jest zawsze pewnym modelem, a nie pełnym, empirycznym opisem ludzkiej natury. Akcentowane są jedynie te elementy, które pozwalają na przeprowadzenie uzasadnienia. Na przykład w koncepcjach liberalnych tradycja i kultura są zwykle pomijane, co wynika $\mathrm{z}$ celu, którym jest podkreślenie zdolności sprawczych jednostki, jej autonomii w zakresie kształtowania własnego otoczenia.

Tak też jest w przypadku lewicy i prawicy - wybór metawartości północnych albo południowych jest uzasadniany odmiennymi poglądami na naturę 
jednostki. W przypadku lewicy akcentowane są cechy pozytywne, a prawicy negatywne. Punktem wyjścia w koncepcji pozytywnej jest przekonanie, że człowiek jest z natury dobry. Jeśli w swoich działaniach postępuje niewłaściwie, przyczyn poszukuje się w jego otoczeniu (są względem niego egzogenne). To bariery zewnętrzne uniemożliwiają jednostkom rozwój, do ograniczeń tego rodzaju można zaliczyć ubóstwo, brak dostępu do edukacji czy dyskryminację. Receptą lewicy na zniesienie tych barier jest realizacja na poziomie polityki państwa równości, społeczeństwa, wolności jednostki, samowładności, pluralizmu systemów wartości, progresywizmu oraz racjonalizmu.

Prawica akcentuje negatywną koncepcję ludzkiej natury. Jej podstawą jest przeświadczenie, że częścią człowieczeństwa jest nie tylko dobro, również zło, które ma charakter endogenny i pojawia się w sytuacji, gdy człowiek świadomie je wybiera. Źródłem zła na świecie nie są, jak w przypadku koncepcji pozytywnej, czynniki niezależne od jednostki - wybór drogi postępowania zależy od niej samej. Ponieważ natura ludzka jest ułomna i niezmienna, na jednostki powinny być z góry nakładane pewne ograniczenia, które w określonych sytuacjach można zmniejszać. Sposobem na przezwyciężenie ludzkich słabości jest postępowanie w zgodzie z systemem reguł określających zachowanie w różnych sytuacjach. Są to normy religijne, moralne i prawne.

Wyróżnione metawartości północne i południowe posiadają strukturę kołową, ale rozpatrywane $\mathrm{w}$ antynomicznych parach tworzą kontinuum linearne. Przykładem niech będzie (ponownie) dyskutowana w Polsce w 2020 roku kwestia aborcji. Lewicowe dążenie do pluralizmu systemów wartości, racjonalizmu i wolności jednostki przejawia się w propozycji liberalizacji prawa regulującego możliwość dokonywania aborcji (opcja „Za wyborem” - pro-choice), prawicowe poparcie dla unitarnego systemu wartości, religii i wolności w ramach wspólnoty w formie postulatu „za życiem” (pro-life), a centrowy kompromis polega na ograniczeniu możliwości dokonywania aborcji do określonych prawem sytuacji (zob. schemat 2). Linearność jest cechą pozostałych sześciu par metawartości.

"kompromis aborcyjny" - ustawa

z dnia 7 stycznia $1993 \mathrm{r}$.

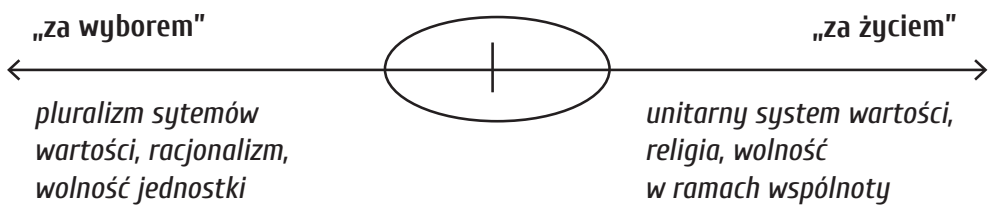

Schemat 2. Linearność metawartości i wartości centrowe - kwestia aborcji w Polsce (oprac. autora) 


\section{Konflikt wokół metawartości a postawy polityczne wobec środowiska naturalnego}

Akceptacja metawartości północnych lub południowych determinuje postawy wobec przyrody. W dalszej kolejności zostanie przybliżona treść tych postaw oraz wskazane przykłady podmiotów politycznych, które je propagują.

Koncepcja prawicowa przedstawia negatywną naturę jednostki, uzasadniając w ten sposób jej preferencje w kierunku metawartości południowych. Jak zostało wyjaśnione, tego typu aksjomaty posiadają naturę konserwatywną oraz są skoncentrowane na samej jednostce. Trzeba podkreślić, że z powodu umiejscowienia w modelu kołowym metawartości typów „umacnianie siebie” i „zachowawczość" są $\mathrm{w}$ naturalnym stanie konfliktu $\mathrm{z}$ równością, społeczeństwem, samowładnościq i wolnościa jednostki.

Prawicowość zakłada postawę, w której to człowiek dominuje nad światem przyrody - co jest wypadkową akceptacji metawartości religia, władza i nierówność. Człowiek nie jest równoprawną częścią środowiska naturalnego, ponieważ to środowisko zostało mu powierzone przez Boga we władanie (metawartości religia, nierówność, władza). Teoria Darwina nie wyjaśnia pochodzenia człowieka, ponieważ czyni to Pismo Święte (konsekwencja metawartości religia). Logicznym rezultatem poparcia dla wyróżnionych aksjomatów jest brak zgody dla rozszerzania praw przysługujących człowiekowi (takich jak wolność, prawo do życia czy godność) na świat roślin i zwierząt. Akceptacja nierówności, religii i władzy determinuje treść postawy, w której przyroda jest podporządkowana człowiekowi.

Trzeba zaznaczyć, że metawartość religia obejmuje różne warianty chrześcijaństwa, których wspólnym mianownikiem jest biblijna idea dominium terrae. W wariancie umiarkowanym sentencja ta jest tłumaczona jako „korzystać i zachowywać" i polega na tym, że człowiek, eksploatując zasoby środowiska, ma jednocześnie obowiązek podejmowania działań na rzecz odwracania negatywnych skutków swojej działalności. Dominium terrae w twardym wariancie jest rozumiana jako prawo człowieka do środowiska naturalnego. Obie interpretacje są charakterystyczne dla podmiotów odwołujących się do wartości południowej części modelu.

Reasumując, w perspektywie negatywnej człowiek dominuje nad środowiskiem naturalnym i ma prawo korzystać z zasobów, które są jego własnością. Stosowanie kosztownych technologii ograniczających negatywne oddziaływanie na przyrodę nie jest niezbędne, ponieważ w konflikcie wartości priorytetem są te w ramach typu „umacnianie siebie”. Oznacza to, że jeśli w zasobach państwa znajdują się surowce, których eksploatacja oznacza wzrost gospodarczy i jednocześnie straty dla środowiska, to preferowany jest wzrost.

Przedstawione podejście do świata przyrody jest trwałym elementem programowym środowisk o etykiecie prawicy. W Polsce postawę wobec środowiska 
determinowaną wartościami południowymi prezentowały (chociaż $\mathrm{w}$ różnym stopniu) podmioty polityczne wchodzące w skład Zjednoczonej Prawicy. W okresie 2015-2020 podejmowano decyzje, które były wyrazem poparcia dla koncepcji negatywnej i wizji, w której człowiek dominuje nad środowiskiem, swobodnie korzystając z jego zasobów. Można tu wskazać na Ustawę z dnia 16 grudnia 2016 roku, określaną przez krytyków jako „lex Szyszko”, zwiększającą uprawnienia właścicieli nieruchomości do usuwania rosnących na ich terenie drzew i krzewów; decyzję o wycince drzew w Puszczy Białowieskiej; przekopie Mierzei Wiślanej; poparciu dla energetyki jądrowej oraz (do końca kampanii prezydenckiej 2020 roku) postawę wspierającą energetykę opartą na paliwach kopalnych ${ }^{4}$. PiS podejmowało decyzje polityczne zgodne z przedstawioną ideą dominium terrae także w okresie rządów koalicyjnych 2005-2007, czego przykładem (i konsekwencją) był spór wokół budowy obwodnicy Augustowa (doliny Rospudy).

Metawartości i wynikające z nich postawy wobec środowiska wydają się uniwersalne w obrębie cywilizacji zachodniej. Na przykład w polityce amerykańskiej aksjomaty południowe i koncepcję negatywną realizował w okresie 2016-2020 Donald Trump. Prezydent wycofał kraj z porozumienia paryskiego w sprawie zmian klimatu, w czasie kadencji negował wyniki badań wskazujących na globalne ocieplenie, podkreślał pierwszeństwo gospodarki przed ochroną środowiska, wycofał też część zmian prośrodowiskowych wprowadzonych przez Baracka Obamę (Trump, 2020). Celem tej polityki było wsparcie rodzimego przemysłu wydobywczego oraz motoryzacyjnego, przy świadomej akceptacji negatywnych konsekwencji dla środowiska. Trzeba zauważyć, że analogicznie jak w przypadku PiS i Zjednoczonej Prawicy, polityka prezydenta Trumpa była zorientowana na wartości zlokalizowane w obrębie typów „umacnianie siebie” i „zachowawczość”, a także oparta na negatywnej wizji jednostki.

W Wielkiej Brytanii UKIP (United Kingdom Independence Party) w manifeście z 2020 roku zapowiadała odejście od rodzimej ustawy o zmianie klimatu z 2008 roku; od porozumienia paryskiego w sprawie emisji dwutlenku węgla z 2016 roku oraz rekonwersję elektrowni na spalające czysty węgiel (UKIP, 2020). Trzeba zauważyć, że analogicznie jak w poprzednich przykładach, postulaty zostały oparte na metawartościach zawartych w ramach typów „Zachowawczość" $\mathrm{i}$ „umacnianie siebie" i wyrażały ideę dominium terrae.

Zupełnie inaczej wygląda perspektywa pozytywna, akcentowana w polityce przez podmioty dążące do realizacji metawartości północnych (które według klasyfikacji na rodziny ideologiczne można przypisać do socjaldemokratycznych, liberalnych, zielonych, a także do powstałych w XXI wieku - pirackich). Ujęcie

Trzeba wskazać na zmiany aksjologiczne, które pojawiły się w polityce Zjednoczonej Prawicy w tej kwestii w 2020 roku. Ogłoszony w sierpniu tegoż roku plan Sasina zakładał, że proces zamykania kopalń jest nieuchronny. Tłumaczono to „przyśpieszoną transformacją energetyczną, wymuszoną przez instytucje europejskie" (Krzykowska, 2020). Na gruncie macierzy zmiana ta jest jednoznaczna i oznacza akceptację progresywizmu w sferze energetyki i paliw kopalnych. 
pozytywne przekłada się na relacje człowieka ze światem przyrody, które są oparte na równości, progresywizmie i racjonalizmie. Wizja ta jest zdominowana przez wartości w obrębie typów „przekraczanie siebie” i „otwartość na zmiany”, są to aksjomaty uniwersalne o wydźwięku progresywnym. Podobnie jak w perspektywie negatywnej, tak i w tym przypadku charakter metawartości przesądza o relacjach człowieka ze środowiskiem.

W podejściu pozytywnym człowiek, zgodnie z teorią ewolucji (element oparty na metawartości racjonalizm), jest częścią przyrody - jednym z jej równorzędnych elementów. Będąc istotą inteligentną i działającą racjonalnie, nie powinien jej niszczyć ani zakłócać istniejącej równowagi. Człowiek powinien dbać o środowisko naturalne, traktując jego elementy w sposób równoprawny (co jest konsekwencją metawartości równość). W tym celu często świadomie musi rezygnować z technologii, które skutkują niszczeniem przyrody, nawet kosztem realnych strat finansowych (metawartość progresywizm).

W polskiej polityce wizja pozytywna była w ostatnich latach obecna w postulatach Lewicy, Koalicji Obywatelskiej oraz Partii Zieloni. Wszystkie wymienione środowiska propagowały koncepcję praw zwierząt, co było logiczną konsekwencją dążenia do równości. W programie Partii Zieloni pojawiła się idea powołania rzecznika ds. praw zwierząt (Program PZ, 2018, s. 35), analogiczna propozycja została zawarta w koncepcji Lewicy z 2019 roku (Polska Jutra, 2019, s. 3). W dokumencie Koalicji Obywatelskiej (Twoja Polska, 2019, s. 104) zaistniała ona w umiarkowanym wariancie (bez propozycji tworzenia instytucji).

W kwestii ochrony środowiska wyróżnione podmioty wskazywały na progresywizm. Zieloni proponowali Nowy Zielony Ład, w którym nakreślili perspektywę transformacji społecznej i gospodarczej. Lewica podkreślała konieczność przejścia od gospodarki opartej na węglu do wykorzystującej zasoby odnawialne. Koalicja Obywatelska proponowała, oprócz wielu różnych innowacji, wsparcie dla wodoru jako „paliwa przyszłości” (Twoja Polska, 2019, s. 102).

Z kolei w polityce amerykańskiej koncepcja pozytywna jest tradycyjną domeną demokratów. W okresie prezydentury Baracka Obamy ekologia stanowiła (oprócz gospodarki i reformy opieki zdrowotnej) jeden z trzech filarów polityki. Realizowano inwestycje w rozwój nowych zielonych technologii: energii wiatrowej, słonecznej i biopaliw (metawartość progresywizm). Zgodnie ze strategią Obamy państwo wspierało tworzenie miejsc pracy w sektorze odnawialnych źródeł energii (metawartości równość oraz progresywizm).

W Wielkiej Brytanii perspektywę pozytywną propagowała w 2019 roku Partia Pracy. Równość stała się podstawą propozycji stworzenia niezależnego od rządu urzędu Komisarza ds. Dobrostanu Zwierząt (Economy, 2019). Progresywizm był źródłem zarysowanej Zielonej Rewolucji Przemysłowej (Green Industrial Revolution), w której transformacja ekologiczna miała stać się impulsem do rozwoju gospodarczego. Dbałość o środowisko wiązano z pozytywną koncepcją jednostki i uniwersalizmem (budowaniem solidarności międzynarodowej, obietnicą poprawienia jakości życia kierowaną do wszystkich). 
Trzeba zaznaczyć, że analogiczne wizje są obecne w innych państwach cywilizacji zachodniej i konstytuują oś sporu politycznego w zakresie relacji ze środowiskiem naturalnym. Można tutaj wskazać chociażby na antynomiczne stanowiska w tej sprawie prezentowane w RFN przez CDU-CSU i SPD z jednej strony, a AfD z drugiej strony; we Włoszech przez Ligę i Ruch Pięciu Gwiazd, w Republice Czeskiej przez ODS i Czeską Partię Piratów.

\section{Wnioski}

W państwach cywilizacji zachodniej można dostrzec korelacje między modelem wartości podstawowych Shaloma H. Schwartza, stworzoną na jego podstawie macierzą metawartości oraz antynomicznymi koncepcjami dotyczącymi relacji człowieka ze środowiskiem naturalnym.

Poparcie dla metawartości południowych, zlokalizowanych w obrębie typów „Zachowawczość” oraz „umacnianie siebie”, jest skorelowane z poparciem dla negatywnej wizji jednostki i idei dominium terrae.

Poparcie dla metawartości północnych, zlokalizowanych w obrębie typów „przekraczanie siebie” oraz „otwartość na zmiany”, jest skorelowane z poparciem dla pozytywnej wizji jednostki, ewolucjonizmu i idei upodmiotowienia przyrody.

\section{Literatura}

Economy (2019). Economy and Energy, https://labour.org.uk/manifesto-2019/a-greenindustrial-revolution/ (dostęp: 21.10.2020).

Fischer, R., Vauclair, M., Fontaine, A.M. et al. (2010). „Are Individual-Level and Country-Level Value Structures Different? Testing Hofstede's Legacy With the Schwartz Value Survey". Journal of Cross-Cultural Psychology, 41(2), s. 135-151.

Huntington, S.P. (1996). The Clash of Civilizations and the Remaking of World Order. New York: Simon and Schuster.

Krzykowska, K. (2020). Sasin: przez obronę nierentownych kopalń nie można doprowadzić do upadku całego górnictwa, https://www.pap.pl/ (dostęp: 13.09.2020).

Maj, P. (2018). Lewicowość, centrowość i prawicowość w nauce o polityce. Rzeszów: Wydawnictwo Uniwersytetu Rzeszowskiego.

Maj, P. (2020). „The Circular and Linear Structure of Political Values and the Three Stereotypes about the Left, Center and Right". Przeglad Politologiczny, 2, s. 59-72.

Polska Jutra (2019). Polska Jutra - program Lewicy 2019, https://lewica2019.pl/images/ media/Program_Lewicy.pdf (dostęp: 22.10.2020).

Program PZ (2018). Program Partii Zieloni, https://partiazieloni.pl/wp-content/uploads/2018/10/program_2018-calosc-rozk\%C5\%82ad-2.pdf (dostęp: 9.08.2020). 
Reedy, W.J. (1981). „Burke and Bonald: Paradigms of Late Eighteenth-Century Conservatism”. Historical Reflections / Réflexions Historiques, 8, No. 2, s. 69-93, www.jstor. org/stable/41298749 (dostęp: 12.05.2018).

Reykowski, J. (2011). „Trzecia Rzeczpospolita a lewica”. W: J. Reykowski (red.). Projekt dla Polski. Perspektywa lewicowa. Warszawa: Wydawnictwo Naukowe PWN.

Routamaa, V., Brandt, T. (2008). „Understanding Cultural Differences the Values in a Cross-Cultural Context”. International Review of Business Research Papers, 4(5), s. $129-137$.

Schwartz, S.H. (1992). „Universals in the Content and Structure of Values: Theoretical Advances and Empirical Tests in 20 Countries". W: M.P. Zanna (ed.). Advances in Experimental Social Psychology. New York: Academic Press.

Scruton, R. (2002). Co znaczy konserwatyzm? Poznań: Zysk.

Singer, M.G. (1954). „The Categorical Imperative”. The Philosophical Review, 63, No. 4, s. 577-591, https://doi.org/10.2307/2182292.www.jstor.org/stable/2182292 (dostęp: 12.05.2018).

Trump (2020). Trump administration to roll back fuel efficiency standards, weakening efforts to combat climate crisis, https:/edition.cnn.com/2020/03/31/politics/trumpfuel-efficiency-standards/index.html (dostęp: 21.10.2020).

Twoja Polska (2019). Twoja Polska: Program Koalicji Obywatelskiej, https://issuu.com/ koalicjaobywatelska/docs/twoja-polska-program-koalicji-obywatelskiej (dostęp: 20.10.2020).

UKIP (2020). UKIP Save Britain National Manifesto 2020, https://irpcdn.multiscreensite.com/f6e3b8c6/files/uploaded/UKIP\%20MANIFESTO\%202020-1.pdf (dostęp: 10.09.2020).

Wendelken, D. (1996). „Contemporary Conservatism, Human Nature, and Identity: The Philosophy of Roger Scruton”. Politics, 16, No. 1, s. 17-22, https://doi.org/ 10.1111/j.1467-9256.1996.tb00142.x (dostęp: 10.05.2018).

\section{Streszczenie}

W przestrzeni debaty publicznej można zaobserwować występowanie antynomicznych postaw dotyczących ochrony środowiska naturalnego. Jedna z nich jest charakterystyczna dla nurtu określanego umownie jako lewicowy, a druga - dla prawicowego. Celem artykułu jest przybliżenie treści i źródeł tych postaw oraz podjęcie próby wyjaśnienia istniejącego na tym gruncie konfliktu politycznego w odniesieniu do psychologicznej teorii wartości Shaloma H. Schwartza.

Słowa kluczowe: ochrona środowiska, lewica, prawica, centrum, metawartości 
